\begin{tabular}{|l|l|l||}
\hline \multicolumn{2}{|c|}{ PublisherInfo } \\
\hline \hline PublisherName & $:$ & BioMed Central \\
\hline \hline PublisherLocation & $:$ & London \\
\hline \hline PublisherImprintName & $:$ & BioMed Central \\
\hline \hline
\end{tabular}

\title{
Anaphylatoxins in the pathogenesis of asthma
}

\begin{tabular}{|l|l|l||}
\hline \multicolumn{2}{|c||}{ ArticleInfo } \\
\hline \hline ArticleID & $:$ & 1623 \\
\hline \hline ArticleDOI & $:$ & $10.1186 /$ rr-2001-68542 \\
\hline \hline ArticleCitationID & $:$ & 68542 \\
\hline \hline ArticleSequenceNumber & $:$ & 34 \\
\hline \hline ArticleCategory & $:$ & Paper Report \\
\hline \hline ArticleFirstPage & $:$ & 1 \\
\hline \hline ArticleLastPage & $:$ & 4 \\
\hline \hline & & RegistrationDate $: 2001-9-18$ \\
& $:$ & Received $\quad: 2000-11-24$ \\
ArticleHistory & Accepted $\quad: 2001-9-18$ \\
& $:$ & OnlineDate \\
\hline \hline ArticleCopyright & $:$ & Biomed Central Ltd2001-9-18 \\
\hline \hline ArticleGrants & $:$ & \\
\hline \hline ArticleContext & $:$ & 129312211 \\
\hline \hline
\end{tabular}


Andrea Heinzmann, Aff1

Corresponding Affiliation: Aff1

Aff1 Wellcome Trust Centre for Human Genetics, Oxford, UK

\section{Keywords}

Anaphylatoxin C3a, asthma, C3a-receptor, guinea pig model of asthma

\section{Context}

The complement system forms a central core of the innate immune defence against a wide range of pathogens. Complement activation leads to a proteolytic cascade whereby the anaphylatoxins C3a and $\mathrm{C} 5 \mathrm{a}$ are liberated as activation byproducts. By binding to their specific cell surface receptors $\mathrm{C} 3 \mathrm{aR}$ and C5aR, respectively, they mediate bronchoconstriction, edema formation and leucocyte activation. An inbred guinea pig strain has been previously described as non-responsive to $\mathrm{C} 3 \mathrm{a}$, though the molecular nature of this defect remained obscure. Guinea pigs are very sensitive to airway antigen challenge and therefore represent a suitable animal model of allergic asthma. The authors used the C3a unresponsive strain to analyse the pathophysiological role of C3a in a model of experimental ovalbumin (OVA)induced allergic asthma.

\section{Significant findings}

Molecular analysis of the guinea pig strain unresponsive to $\mathrm{C} 3 \mathrm{a}$ revealed a point mutation within the coding region of the $\mathrm{C} 3 \mathrm{aR}$ creating a premature stop-codon and thus effectively deleting one third of the receptor. To confirm the functional importance of the deletion of the distal one third in the $\mathrm{C} 3 \mathrm{aR}$ protein, human HEK 293 cells were transiently transfected with the wild-type and the mutant genes. A minor expression of the mutant $\mathrm{C} 3 \mathrm{aR}$ was found by flow cytometry, however, no binding of $\mathrm{C} 3 \mathrm{a}$ to the truncated receptor could be detected. When challenged by OVA inhalation, sensitized animals with the defective gene for $\mathrm{C} 3 \mathrm{aR}$ showed a significantly decreased bronchoconstriction in comparison to the corresponding wild-type strain. In contrast, no difference in IgG titres was observed between both groups and the eosinophil influx as well as the amount of eosinophil peroxidase in lung homogenates were equal in both strains. 


\section{Comments}

Similar observations have been published very recently underscoring the importance of the complement-derived anaphylatoxins in the pathogenesis of asthma (see Additional information). One study found decreased bronchial hyperresponsiveness in C3aR knockout mice compared to wild-type mice, but also no effect on eosinophil influx. Furthermore, complement factor 5 has been identified as a susceptibility locus for experimental allergic asthma in mice. Taken together these three studies provide for the first time substantial evidence for complement factors modulating susceptibility to asthma. They strongly suggest that, in addition to well known acquired immune response mechanisms, the innate immune system and in particular complement are involved in the pathogenesis of asthma in animal models. If these results were confirmed in humans this pathway could provide a novel target for drug intervention strategies in human asthma.

\section{Methods}

Guinea pigs (wildtype and C3a unresponsive), transfection of HEK 293 cells, flow cytometry, C3a binding assays, whole-body phlethysmography, histochemistry, IgG ELISA, eosinophil peroxidase assay

\section{Additional information}

Humbles AA, Bao L, Nilsson CA, Lilly C, Israel E, Fujiwara Y, Gerard NP, Gerard C: A role for the C3a anaphylatoxin receptor in the effector phase of asthma. Nature 2000, 406:998-1001.

Karp CL, Grupe A, Schadt E, Ewart SL, Keane-Moore M, Cuomo PJ, Kohl J, Wahl L, Kuperman D, Germer S, Aud D, Peltz G, Wills-Karp M: Identification of complement factor 5 as a susceptibility locus for experimental allergic asthma. Nature Immunol 2000, 3:221-226. 


\section{References}

1. Bautsch W, Hoymann HG, Zhang Q, Meier-Wiedenbach I, Raschke U, Ames RS, Sohns B, Flemme N, Meyer zu Vilsendorf A, Grove M, Klos A, Kohl J: Cutting edge: guinea pigs with a natural C3areceptor defect exhibit decreased bronchoconstriction in allergic airway disease: evidence for an involvement of the C3a anaphylatoxin in the pathogenesis of asthma. J Immunol. 2000, 165: 5401-5405.

This PDF file was created after publication. 